\title{
PUTTING THE HUMAN AT THE CENTRE: HUMAN RIGHTS AND LITERARY STUDIES IN SOUTH AFRICA
}

\section{T. Ndlovu}

Department of Arts

Walter Sisulu University

Mthatha, South Africa

e-mail: Thabsndlovu@gmail.com

\section{ABSTRACT}

Drawing on my teaching experience of Human Rights and African Literature, particularly the unpacking of "human" in human rights, this article argues for revitalising and deepening the study of literature in South African universities, with the aim of reconstructing and (re)humanising societies. Through focalising the imbrication of story/narrative with the human and rights, the article uses specific lecture/class room experiences to suggest another way of reframing enduring historic modes of perception, some of which tend to the inhumane or "monstrous". Given its emphasis on basic human rights such as dignity, equality and freedom, rights-reading coupled with a reflexive methodology to the teaching and learning of literature, can contribute to an informed citizenry. The article suggests that such approaches point to the future of literary scholarship - interventionist and interdisciplinary.

Key words: human rights, African literature, South Africa, story, humanising

"It is only the story ... that saves our progeny from blundering like blind beggars into the spikes of the cactus fence. The story is our escort; without it, we are blind .... It is the thing that makes us different from cattle." Chinua Achebe, from Anthills of the Savanah

\section{INTRODUCTION}

In 2011, two lectures into the course, a student in my African Literature and Human Rights course, who was one of four South African students under the International Human Rights Exchange Programme (IHRE) at the University of the Witwatersrand (Wits) helping to coordinate a tour to Soweto, made four instructive, if not vexing comments. One of them was, "But some of these foreigners are too much". He had walked with me to my office to get a signup form. In the just ended lecture, we had discussed migration and xenophobia in Phaswane Mpe's Welcome to Our Hillbrow (2001) as well as ghastly online images of some victims of xenophobic attacks. It had led to a general discussion on violence in South Africa, including against gays and lesbians in townships. We condemned these barbaric acts.

I asked him to explain his point on foreigners. "Some of these people even pretend they own the whole place and can really get on your case [be provocative]", he responded. I queried 
whether he was justifying xenophobic killings and why he had not raised this in class. Although his response displayed reasonably sound knowledge of human rights, it was constantly qualified with a "but". For example, he knew what he had just told me was not "politically correct" but had merit, and as a South African myself, I ought to understand.

The second comment concerned what the student called "this gay thing". He spoke against gays and lesbians and whites - all in the same breath. His third comment or question, was whether African literature "belonged with human rights". He argued it did not. Passionately, he spoke of Africanness and mentioned the fourth critical comment - the duplicity of the champions of human rights like the United States of America who were committing gross human rights abuses. What surprised me was the raw passion with which he spoke. That had not happened in the three years I had been teaching the course. Although I was quite upset, my overriding feeling was sadness. I realised that Jabu (as I will call him), had the "guts" to say what he had because of an assumed affinity and alliance. It was "cash talk" between two black heterosexual South African males, who could safely put aside the political correctness of the lecture/class room. He was correct on all these general descriptors except one - I am not a South African. ${ }^{1}$ What really saddened me was his suggestion that we had our own elevated humanity; that it was one thing to talk human rights but quite another to practise them.

Jabu triggered many questions. How was I to interact with him, knowing he would resist all that the course stood for? What if he aired his "problematic" views in class? Should I deal with him in private? Addressing these worries through the course content and pedagogical methods appeared to be the most attractive and professional way. The decision prompted questions of its own. Why and how was I teaching the course? What were my assumptions about human rights and African literature? Was I uncritically offering rights-reading of literature as an antidote to rights abuses? To what extent did the course explore the controversy of human rights regarding their genesis and practice in different eras and geographical spaces? Had I created an atmosphere that made my classes rather too safe for both myself and the students by foreclosing contentious ideas and sentiments? If I encouraged students to express politically incorrect views, would that not be too difficult and dangerous to handle? Had we really unpacked the "human" in human rights? Lastly and most significantly, how could I make the conception of rights go beyond individual entitlement? This essay attempts to answer these questions and more. It is based on personal reflection, a journal I kept, student/class dialogue, notes made during student presentations and comments made by students in evaluating the course. 


\section{TEACHING HUMAN RIGHTS AND LITERATURE AT A SOUTH AFRICAN UNIVERSITY}

In 2008, I was approached to teach African Literature and Human Rights. I agreed because I would get a chance to foreground a concept I had been making an oblique reference to in my teaching of literature. I felt it potentially held the key to critically reflect on individual and collective responsibility. It was a chance to directly engage with human rights education and to explore its possible efficacies. The interdiscipline of African literature and human rights offered a fascinating and fresh approach towards that end. It was an opportunity to go beyond the staple appraisal of literary texts, to see what the literary narratives would bring to the understanding of fundamental human rights instruments such as the Universal Declaration of Human Rights (UDHR), on which the South African constitution of 1996 is based (Osler and Zhu 2011).

I was convinced that the interdisciplinarity of African literature and human rights would re-energise not only the study of African literature but human rights with reference to the African context in general and the South African one in particular. I co-taught the course with a North American colleague in a collaborative arrangement that proved productive. The small seminar-style classes of between ten and fifteen students, facilitated deep engagement. My conversation with Jabu precipitated my changing the course content and some pedagogical approaches when I taught the course alone.

By 2011, some liberal arts colleges in the USA were offering literary studies and human rights and have since increased in number (Dawes 2016). It is very likely that in South Africa, only Wits offered such a course. Apart from the one I lectured on at Wits, as at 25 July 2017, an internet search for such a course in South African universities did not return results. I last offered it in 2013 when IHRE disbanded. The lack of courses in literary studies and human rights in South African universities is an anomaly for two reasons. First, "human rights and education are priorities for the South African political and educational systems" (Roux 2012, 30). So, a more expansive educational endeavour including humanistic disciplines such as literature is expected. Second, given that literature projects the human being who bears rights, its omission in efforts towards achieving justice and equity is curious, especially considering the central role that literature played in the fight against apartheid by having it declared a crime against humanity. Given literature's potential to humanise in the dismantling of apartheid, it was inexplicably neglected in the project of humanising post-apartheid South Africa. In South African universities, human rights as a discipline is predominantly studied under the traditional disciplines of law and social sciences or it is offered as human rights education in education faculties, aimed at the "facilitation of human rights literacy in teacher training" (Becker, De Wet and Van Vollenhoven 2015, 1). 


\section{CONTROVERSY AND PARADOX OF HUMAN RIGHTS}

It is important to comment on the controversies and paradoxes of rights before discussing the intersection of African literature and human rights, and the modifications I made to teaching and learning of African literature and human rights. After the exchange with Jabu, I realised that maybe this aspect was insufficiently emphasised. Making clear the controversies and paradoxes of rights points to the self-critique that should accompany human rights education. In any case, human rights oriented literary criticism "engages in both reflection upon and critique of the theories of the liberal subject and the liberal democratic state that underlie the modern international human rights system" (Goldberg and Moore 2012, 3). Human rights as concept, discourse and practice has its own philosophical, political and practical limitations. As Lechte and Newman (2013, vi) suggest, the human rights project could be said to be in crisis, almost to a point of "impotence" given continued gross human rights violations by despots and the very countries that claim to champion human rights. Davis $(2013,108)$ writes of inherent "contagion" in human rights given the "inescapable imbrication of human rights with the global capitalist mode of production that is their historical condition of emergence". Some argue that because human rights and their institutions as we know them have a "westcentric history" (Goldberg and Moore 2012, 3), both need localisation. As Szeghi (2012, 245) notes, some critics claim that the human rights discourse, particularly its portrayal of postcolonial contexts, recycles the "imperialist discourse" of the colonial days to "justify Western interventionism, with human rights activism being the West's current civilizing mission." Clearly, human rights are riddled with inconsistences, paradoxes and weaknesses, and are often contested.

I took pains to stress and explore in my class (particularly after the conversation with Jabu) for its conceptual and pedagogical value, the paradox that "the most basic of all rights is the right to be human, and to remain human" (Baxi, 1997 cited in Becker, De Wet and Van Vollenhoven 2015,3). What should be a banality - consistent recognition of fellow humans as humans and according them the same humanness we claim for ourselves, is a complex and politically charged project. Being human and deserving of rights is not a "given". Messer (1993, 222) writes:

"Human rights as a philosophical concept refers to the reasonable demands for personal security and basic well-being that all individuals can make on the rest of humanity by virtue of their being members of the species Homo Sapiens ... But what these rights are, and who is protected under them, has varied according to historical and social context and political interest."

On the surface, human rights are rights people have because they are human. Such rights are 
“possessed innately by virtue of one's humanity, inhering in the individual, grounded in reason and nature, neither granted by nor capable of obliteration by any earthly power" (Peters 2012, 22). Yet the concept of who is human was never self-evident right from earlier attempts at enshrining rights, such as the American Declaration of Independence of 1776 and the French Declaration of the Rights of Man and Citizen of 1789 and 1793. Both excluded some races and classes. When the UDHR was adopted by the United Nations General Assembly in 1948, some of the signatory countries held colonies in Africa and as expected, the document was silent on decolonising. Disenfranchised indigenes had to fight for human rights in colonised Africa due to the racist colonial claim that they were less human or in extreme cases of racist bigotry such as apartheid, non-human. Characterised by extreme depersonalisation and dehumanisation, apartheid stands as an example par excellence in which "apparent humans [did] not qualify as humans according to established judicial norms" (Butler 2006, 1659).

Thus, during the founding and development of human rights, some humans were "declared nonhuman" (Stanton 2006, 1521). This "exclusion of some people from the human community" (McClennen and Slaughter 2009, 1) confirms that being "human" is not apparent. As Solomon (2006, 1589) states, it is designated, meaning it can be conferred or denied. The question of who is a "full person" (Messer 1993, 228) eligible to enjoy human rights continues to manifest in different forms of exclusion and aggression such as xenophobic attacks, hate crimes against LGBTI communities, domestic violence, and in the utterances of disqualification that Jabu made. Such instances remind us that "societies ascribe and individuals achieve human dignity" (Messer 1993, 228), creating in the process, vulnerable outcasts perceived to have "failed to meet minimum standards of behaviour [...] and personhood" (Messer 1993, 228). Sometimes, this categorisation decides who lives and who dies.

Despite their paradoxes and controversies, human rights, through rights-reading of literature are a potent force. The interdisciplinarity engages concepts of the human and rights from different positionalities and historical moments, always focalising the rights-bearing subject. Regardless of their controversy, human rights are a useful tool in understanding evil and oppression occasioned by the disqualification of others from the human family. Human rights constitute a "moral vocabulary" (McClennen and Slaughter 2009, 1) with ethical codes, some of which are enforceable by law. But human rights have no magic formula for fixing the world. They are proclamations that aim to create a safe and humane world for all despite their inherent weaknesses, and should be regarded as a project in progress and not an infallible doctrine and practice. The paradoxes in both the discourse and practice of rights remind us that a course like African Literature and Human rights should be taught in a self-reflexive manner that critiques human rights as its main subject, and its own wider aims and methods. Human 
rights must be challenged, just like any other ethical claim (Osler and Zhu 2011), and if human rights education is to be of any use, it must challenge both the educator and students to critically reflect on their humanness as individuals within various collectives, to "explore their multiple identities" (Osler and Zhu 2011, 224). Three memorable classes I conducted between 2011 and 2013, presented below, illustrate this claim.

\section{LITERATURE, STORY AND HUMAN RIGHTS}

Above, I referred to literature and human rights, as if they naturally belong together. Jabu challenged me to clarify the relationship not just between literature and human rights but African literature and human rights. The relationship between literature and human rights is not always clear or adequately acknowledged. Slaughter (2012, xii-xiii) writes:

"Literature and human rights may have intersected only recently as common or overlapping areas of scholarly inquiry, but the two have been bound up with one another ... for a very long time.

[Also] literary works and literary modes of thinking have played important parts in the emergence of modern human rights ideals and sentiments, as well as in the elaboration of national and international human rights laws."

Peters $(2012,24)$ observes that, "It has often been noted that literary and legal rhetoric were once inseparable [...] and the same can be said for the rhetoric of rights". Dawes $(2009,396)$ mentions "the deep history of literature and human rights" and cites various arguments about how the production, circulation and consumption of certain novelistic and other narrative practices inspired human rights. Some novels such as the epistolary and the sentimental popularised ideas about autonomy, equality and empathy (Dawes 2009). Slaughter $(2006,1406)$ cites instances where in revising the UDHR, delegates invoked Robinson Crusoe by Daniel Defoe to clarify "human personality" and its relationship with the wider "community". By authoring an "enabling fiction" towards the creation of human rights, "Daniel Defoe took his official place among the unacknowledged legislators of the world". Thus, literature as a discipline is part of the birth and development of human rights discourse and practice.

In the African context, the relationship between human rights and literature might not have been strong in the early years of the establishment of human rights codes. However, with growing calls to decolonise, narratives classified as protest literature or anti-colonial, did raise issues of human rights. Things Fall Apart by Achebe (1958), raises concerns around dignity, equality and freedom, as does Coetzee's Waiting for the Barbarians (1980). A myriad of postcolonial African texts focus on the abuse of state and other powers, showing that the rights that had been promised during the anti-colonial struggle have been usurped by "liberators" as shown 
in Noviolet Bulawayo's We Need New Names (2013).

The importance of story to the genesis and propagation of the human rights regime cannot be overemphasised. At the centre of human rights and literature is story-telling or narrative and representation (Butler 2006). Practical human rights work is driven by narrative, as Dawes $(2009,394)$ points out:

"[H]uman rights work is, at its heart, a matter of storytelling. Many of the most recognizable organizations that intervene in humanitarian crises do so in large part by using language instead of food, medicine, or weapons; the most important act of rescue for them is not delivering supplies but asking questions, evaluating answers, and pleading with those of us who observe from a distance."

Narrative and representation are equally central to human rights work, the humanities and language. Literary narratives that bear witness to suffering put a face to human suffering.

Literature and human rights depend on rousing empathy and underscoring shared humanity. The emotive in literature appeals to our sense of the moral in the same way that the key concept of humanism in human rights drives the philosophy of human rights. Literature adds to the verbal and visual stories of rights. Such literature through its affective appeal, asks the African literature and human rights lecturer and student to critically reflect on their humanness - to be an embodied, time-framed and moral subject with responsibility to self and others (Palumbo-Liu 2012). Considering Jabu's comments, how could I defamiliarise the students' understanding of their humanness to prompt them to critically reflect on that of others? I revised the existing content and pedagogical methods. But first, I present the underlying philosophies of rights-based criticism of literature, earlier pedagogical methods, followed by a discussion of "new" or added pedagogical methods that I employed.

\section{RIGHTS-READING OF AFRICAN LITERATURE: UNDERLYING PHILOSOPHY AND ASSUMPTIONS}

The African context and its literary output both add to and complicate our understanding of the concepts human and rights given the histories of colonialism, decolonisation and post-colonial challenges of all kinds. Certain philosophies and assumptions about the efficacy of conducting a rights-reading of literature in general, and what the peculiarities of the African continent, and South Africa in particular, add to our understanding of human and rights informed my teaching of the course.

The key guiding tenet was that humans are rational; we can process the world and reflect on our place in it and make choices informed by that rationality (Palumbo-Liu 2012, 21). 
Literature offers us not just a "second handle on reality" (Achebe 1988a, 27), but one of the most important handles on reality. "Humanistic materials" such as written literature "can raise profound questions, appeal to the imagination and moral sensibilities, and engender critical and creative thinking" (Twiss 2005, 219) about humanity. Accordingly, literature can offer psychological insight into, and emotional identification with victims of human rights abuses, warning us that we may find ourselves in similar positions of precarity where we require others to exercise responsibility for our survival or humanness. Just as human rights are about "what should be" (Twiss 2005, 226), a rights reading is equally aspirational as it seeks through its ethical approach, to "re-humanize" (Davis 2013, 102).

The broad aims of my course coincided with those of human rights education in general. Human rights education, or rights-based education, is one "informed by human rights norms and standards", which through a "humanising practice" aims to "contribute to positive social transformation and social cohesion in and through education" (Becker, De Wet and Van Vollenhoven 2015,2). Its main thrust is "transformative action [...] towards an open democratic society" (Becker et al. 2015, 1). In this regard, I facilitated a type of education geared toward "consciousness raising" through "critical reflection on assumptions" (Zinn, Adam, Kurup and Du Plessis 2016, 75). The best way to achieve it was through a humanising pedagogy. Delport $(2016,8)$ comments that, "at the heart of a humanising pedagogy is people's humanity - and that all human beings are equal in their humanity." Consequently, dialogue in a rights-reading class becomes key, given its "acknowledgement of situated selves and [...] the ontological need for, and right, to voice" (Delport 2016, 8).

To contextualise the course, between 2011 and 2013, I used the following texts: Ngugi wa Thiongo's A Grain of Wheat (1967), to foreground colonisation and decolonisation in Kenya; Fugard, Khani and Ntshona's Sizwe Banzi is Dead (1974) to scrutinize the dehumanising effects of apartheid; Coetzee's Waiting for the Barbarians (1980) to explore torture and complicity in oppression; Marechera's The House of Hunger (1978) to examine psychological effects of colonisation; Dangarembga's Nervous Conditions (1988) to probe gender inequality; Mpe's Welcome to Our Hillbrow (2001) to scrutinise xenophobia and HIV-AIDS in South Africa, and Diop's Murambi: The Book of Bones (2006) to analyse the Rwandan genocide. Four texts were studied each semester.

Before the challenge from Jabu, the course consisted of two tasks plus a written examination. The first task was an oral presentation on creative texts and relevant critical material while the second was a written common assignment on the same. To increase personal involvement and dialogue, I changed the second assignment to an oral presentation. The scoring for the first oral assignment included the oral presentation and a write up on the same (25\%). 
The scoring for the second focussed solely on the oral presentation, particularly the teasing out of the "human" (25\%). It required students to respond to any human rights incident within the last five years they felt strongly about or found significant. This was partly my response to Jabu. I hoped that Jabu or some of the other students would take up some of the contentious issues such as land restitution, xenophobia and homophobia so we could openly and critically tackle these issues. Below, I present three of the most memorable student presentations. They illustrate the idea that learning about human rights should entail going beyond banking knowledge, to testing its application, and demonstrating that "arts-based methodologies [have] healing and humanising possibilities" (Delport 2016,7) if we sincerely grapple with the human in rights.

The first presentation was by a black female student who self-identified as a Rastafarian. Her hero was the late South African reggae star, Lucky Dube. She chose the trial and eventual sentencing of Dube's killers on 31 March 2009. Dube was shot and killed in a carjacking incident on 18 October 2007. Dube's shooter said he had mistaken him for a Nigerian. The presenter used this incident to "meditate" on humanness and blackness globally. She lamented the "mental slavery" of the African which resulted in "self-hatred", a condition that cheapened black lives. Dube's murder, she concluded, was a case of Afrophobia. It indicated how conversely, Caucasians, Indians and the Chinese were accorded humanness and even godlike status.

Most of the students agreed with her sentiments and views. However, two students, including Jabu, objected. One said the murder of Lucky Dube was terrible, but was the presenter not too idealistic in preaching peace and love when a lot of South Africans were angry over foreigners? "Out there", added Jabu, most people were not smoking zol (marijuana) and "hugging the next brotherman and singing kumbaya." Some of the comments were derisive. I reminded the class of the importance of respecting others' religions. The presenter remained calm and said she expected people to poke fun at Rastafarianism by focusing only on the smoking of marijuana. The rest of that class progressed well, with some students citing the absurdity of guessing one's nationality through looks, a case being that some South Africans deemed too dark had been attacked and killed during the xenophobic attacks of 2008. They made reference to how Mpe (2001) exposes some of the prejudices against foreigners, at which point the presenter suggested that the label "foreigner" was hateful, connoting strangeness and inferiority. Although I expected Jabu and colleague to challenge these egalitarian ideas, they did not, possibly because the rest of the class condemned arbitrary and dangerous divisions amongst Africans.

The second presentation was in 2012 by a black male student who self-identified as an "Africanist". He presented the story of a white farmer who, in 2011, shot and killed a black 
man he had mistaken for a baboon. The presenter cited three similar cases before that one in the previous five years. The consistency, he argued, showed that white farmers were racist as they saw black people as baboons to be shot for sport. The white farmers were the incorrigible "Thompsons"2 of the world. Whites, the presenter concluded, were not "really human"; they would only become "proper" humans after suffering.

Most of the class vehemently disagreed with his conclusion and went back to the UDHR's basic definition of human and other religious and secular definitions. Unconvinced, the presenter argued that whites all over the world enjoyed and continued to enjoy "too much safety and privilege". At that point, a white female student who lived in a farming area where farm attacks were common, challenged the claim that whites enjoyed "too much safety" by citing violent crimes including murder, that were being committed against white farmers. She argued that the attacks were racial in nature and were a serious human rights issue to which the government paid scant attention, especially after disbanding Commandos that used to effectively defend the farmers. The Africanist said white farmers were victims of crime like everybody else in South Africa; crime in general had to be fought as it affected everybody and not only a "special" group. A very emotional debate ensued. The white student asked the "Africanist" if he knew what it was like to live on a farm, knowing any day might be his last, to which the latter asked if she knew what it was like to live with the everyday violence of the township all her life. Then came accusations and counter-accusations of racism, raised voices, tears of anger and frustration until I asked for time out during which we would be quiet for two minutes, catch our breath and remember to be respectful towards each other. When we resumed, we had a calmer discussion on the relationship between humanism, race and racism, power, and privilege.

Following that session, I developed what would become known as check-in moments. These came at the beginning of a new lecture, signalling the beginning of a new session and reflecting on the previous one, to see if we were all alright. They proved to be most edifying moments as feelings of anger, suspicion and uncertainty were addressed, most of them quite effectively and some not so much. Check-in moments were useful tension de-fusers during which students expressed concerns and clarifications. Some, including me, made apologies. Check-in moments also worked to prime students for the day's session - to guard against extreme anger, and infringement of others' rights. As one student wrote on an evaluation form concerning the most useful part of the course, "certainly check-in moments [as they] taught me to reflect and understand some of my classmates".

I started reading up on pedagogical skills employed in courses such as mine. The most useful article was by Davis and Steyn (2012). They argue that "when working with liberatory 
pedagogies towards conscientising people from dominant positionalities" (Davis and Steyn 2012, 29), conflict is not only unavoidable but necessary. They make an instructive observation that dominant positionalities are not clear-cut, given the "complex interplay between oppressed and privileged identities that can be a part of the same individual", hence the need to "teach about hegemonic identities, power, privilege and oppression” (ibid., 30). Teaching these sometimes requires "firmly challenging students" (ibid., 30) even though they might feel uncomfortable. The two scholars recommend that the educator should get over the fear of student resistance and "outbursts" (ibid., 31) and use conflict as an opportunity for new thinking and growth. They conclude that trauma and crisis accompany growth, and confrontation might be preferable to maintaining a "false sense of community" (ibid., 33). However, this robust engagement must be tempered by close attention to the tone and mood of each exchange among students and between the lecturer and students, with care being taken not to make students so uncomfortable that they feel their right to safety in the lecture room has been violated. Carefully considered and consistent dialogue is needed towards that end.

The last memorable student presentation was in 2013, by a black male student, who chose the trial in April 2011, of nine men accused of killing a black woman, Zoliswa Nkonyana, in 2006, for being a lesbian. The presenter argued that because of police bungling and the reluctance by various arms of the law to treat it with the seriousness it deserved, the case had dragged unnecessarily. For Nkonyana, he argued, race, sexual orientation and poverty, had all weighed against her, making her almost non-human and invisible in many people's eyes. He added that if she were a white woman, irrespective of sexual orientation, whose head had been bashed to a pulp, there would have been a national uproar and the wheels of justice would have turned faster. A student questioned the wisdom of living openly as a lesbian in a township. Others got angry and accused him of blaming the victim of hate, and failing to understand the basics of sexual orientation. A heated debate followed on the unAfricanness of being gay and biologist condemnations of being gay and so on. Other students offered lessons on the complexities of human sexual orientation and desire and one declared that she was a lesbian. I contributed to the debate by delineating typologies of oppression and hate, stressing that what changes is the category and target. I underlined the importance of embodiment in rights; that the human being we speak of in rights has a body and bodies are as different as people are.

\section{COURSE EVALUATIONS}

These three selected presentations represent numerous dialogues on the human and rights that pedagogical adjustment made possible. Another dialogue was in the form of students' comments on the course during evaluations. Regarding the text selection, there was general 
satisfaction. One student thought it was "amazing". Some "learnt a lot" and discovered that there was more to literature than the rudiments of "plot, setting and all that". Another cited skill was the ability to "listen with little prejudice". Another referred to realising that rights go with obligations, "I never knew that being human is a job on its own." One student wrote that s/he would always remember the phrase, "We are all made of the same stuff", taken from a poster on my office wall and from lectures where I pointed out instances of human commonalities, including blood transfusion and organ transplantation. There were those who found the course edifying, exemplified by the student who thought s/he had become a "better human being".

"Negatives" included student discomfort, which nonetheless, as pointed out already, was carefully handled. Some students were uncomfortable with "bits that drew [them] out" as this put them "on the spot". One student captured the emotionally intense moments "when sparks were really flying". As already mentioned, to disrupt acculturated ways of seeing, both educator and students may need to experience some level of discomfort and refuse to be dominated by fears because "[these] fears, though understandable, are not useful, especially if out of the fear of causing discomfort for students or themselves, educators change their pedagogies by either avoiding hard truths or telling half-truths" (Davis and Steyn 2012, 31).

Some students felt discomfort because sexual orientation was "people's private stuff". If human rights are practicable, however, it is important to stress the embodied politics of reading for rights to increase our vocabularies of perception regarding embodied human experience - a direct way of focalising the "human". Often we forget, as cited in one of the presentations above, that we occupy bodies on which all kinds of social codes, including those of exclusion and hate are scripted. Related to sexual orientation, a student commented that I had failed to lead by example by labelling one student a homophobe. I had had to make the student realise his heterosexual privilege and see that he was tending towards the inhumane or evil by expressing hate. Human rights education is values education, and rights-reading should enable us to identify that which is not humane, "the monstrous" (Butler 2006, 1661) and call it out. An educator's failure to do so regarding all forms of prejudice and hate amounts to failing the class (Davis and Steyn 2012).

Other negative comments asserted the "unAfricanness" of some things on the course. Some expressed unhappiness with the interdisciplinarity of the course, and asked "Is this literature or Psychology?" Such unhappiness shows that despite noble intentions, transformative learning may not happen, and, even if it does, it may not happen immediately. Zinn et al. $(2016,76)$ observe that transformative learning implies that

\footnotetext{
"a person could become more tolerant or even less tolerant towards an individual or group, look
} 
with different eyes at another person or group, or alternatively become more biased or prejudiced towards an individual or group."

Throughout this article, it was assumed that emotional identification with victims of human rights abuse could be facilitated by works of art. However, as Lauritzen $(2005,244)$ observes, works of art can also "facilitate a process of emotional distancing".

About a year after Jabu attended the course, I received an email from him. He apologised for having said "some things about foreigners and other people"; things he ought not to have said "about any human being". I was happy that I had raised questions, inspired engagement and argument about the human, heightening students' awareness of available moral choices. It was proof of the assertion that "education has the potential to facilitate catalytic transformation of society" (Delport 2016,8), although we may not agree on methods of such facilitation and can never know the depths of the knowledge and conviction behind that transformation, if it happens.

\section{CONCLUSION}

I started this article by narrating one after-class incident in 2011. I used the incident with Jabu as a prompt and to demonstrate the centrality of story in human rights, and indeed, teaching for human rights through literature. Dawes $(2009,395)$ observes that, "We make sense of ourselves and our lives, individually and collectively, by telling stories." I take the notion of telling stories to refer to literary narratives, everyday dialogue, lecture/classroom dialogue, and indeed the way we live our lives. The epigraph at the beginning of this essay, taken from Achebe's (1988b) novel, claims that human beings are stories - each one of us is a narrative inserted in a longer and complex socio-historical narrative web. Stories differentiate us as communities and individuals and stories also suggest our common humanity. Narratives attract us because we derive identities from them and as Achebe suggests in the epigraph, stories as memorialisation and guides for responsibility towards others, set us apart from animals. We are different from animals because we are moral beings, and narrative makes it possible to have moral conversations (Osler and Zhu 2011). Human rights are a moral force and once we unpack "human" and keep our thoughts and dialogue firmly on humanising, their morality can be realised, making sure that we

"name productively our own complex subject positions with their relative powers and privileges in relation to others without succumbing to the paralyzing force of negative identity politics, seeking instead an ethical position from which to forge solidarity across difference" (Goldberg and Moore 2012, 10). 
Jabu's utterances typified "moral blindness" (Twiss 2005, 220) and the paradoxes of human rights as concept and practice - chiefly that human rights appear so self-evident we do not realise the complexity of the term "human" itself. True to the origin of human rights, the concept of who is "human" has been and will continue to be deployed selectively; to be self-evident yet hidden and highly contested. Some of Jabu's habitual assumptions and convictions were limited and dangerous. They needed to be disrupted so he might re-envision himself and others. I afforded him space to think about his humanity versus that of others, through dialoguing with the literary texts, fellow students and I. The content and pedagogy that informed the course aimed to enable learners to explore their situatedness in both power and precarity. This undertaking acknowledged the idea that education is the "construction and reconstruction of personal and social stories" (Connelly and Clandinin 1990, 2). Students could creatively engage the messiness of what it means to be human. Their comments suggest the extent to which literary and rights discourse were used to widen the definition, not just of the human, but a human with rights.

I do not claim that human rights and literary studies are a novel panacea for social ills. Rather, I propose the teaching of African literature, or any kind of literature, through a human rights lens, as a sensitisation tool to focus on the "human" in human rights. Literature reminds us in its projections of characters as well as other literary techniques that rights are for people. It is the human being who has rights that go beyond individual entitlements. The teaching of human rights through literature or rights-reading of literature, is one of the best intellectual resources we have for the internalisation of the ideals and the observance of human rights. The teaching must be done in a way that encourages reflection and reflexivity all round, given that effective human rights education is "neither caught up in human rights idolatry or cultism, nor is conservative and uncritical" (Keet 2012, 9). In South African universities, there are few, if any, literature courses of the sort that defamiliarise the oft bandied but least understood concept of human rights.

\section{NOTES}

1. Jabu had erroneously concluded, from my names, that I was South African. This happens frequently. Both my first name and surname can be thought to be from the Zulus of KwaZuluNatal or the Ndebeles of Mpumalanga. I am Ndebele but Zimbabwean.

2. The character John Thompson in Ngugi's A Grain of Wheat (1963) becomes exceedingly violent and openly racist as the anti-colonial war intensifies. 


\section{REFERENCES}

Achebe, C. 1958. 1986. Things fall apart. Reprint Oxford: Heinemann.

Achebe, C. 1988a. Hopes and impediments: Selected essays. New York: Anchor-Doubleday.

Achebe, C. 1988b. Anthills of the Savannah. New York: Anchor Books.

Baxi, U. 1997. Human rights education: The promise of the third millennium? In Human rights education for the twenty-first century, ed. G. J. Andreopoulos and R.P. Claude, 142-154. Philadelphia: University of Pennsylvania Press.

Becker, A., A. de Wet and W. van Vollenhoven. 2015. Human rights literacy: Moving towards rightsbased education and transformative action through understandings of dignity, equality and freedom. South African Journal of Education 35(2): 1-12.

Bulawayo, N. 2013. We need new names. Harare: Weaver Press.

Butler, J. 2006. Afterword. PMLA 121(5): 1658-1661.

Coetzee, J. M. 1980. Waiting for the Barbarians. New York: Penguin.

Connelly, F. M. and D. J. Clandinin. 1990. Stories of experience and narrative inquiry. Educational Researcher 19(5): 2-14.

Dangarembga, T. 1988. Nervous conditions. Seattle: Seal Press.

Dawes, J. 2009. Human rights in literary studies. Human Rights Quarterly 31: 394-409.

Dawes, J. 2016. The Novel of Human Rights. American Literature 88(1): 127-157.

Davis, D. and M. Steyn. 2012. Teaching social justice: Reframing some common pedagogical assumptions. Perspectives in Education 30(4): 29-39.

Davis, E. S. 2013. Contagion, cosmopolitanism, and human rights in Phaswane Mpe's "Welcome to our Hillbrow". College literature. A Journal of Critical Literary Studies 40(3): 99-112.

Delport, A. 2016. Humanising pedagogies for social change (Editorial). Educational Research for Social Change 5(1): 6-9.

Diop, B. B. 2006. Murambi the book of bones. Bloomington: Indiana University Press.

Fugard, A., J. Khani and W. Ntshona. 1986. [1974]. Sizwe Banzi is dead. New York: Theatre Communications Group, Inc.

Goldberg, E. S. and A. S. Moore. 2012. Introduction. In Theoretical perspectives on human rights and literature, ed. E. S. Goldberg and A. S. Moore, 1-16. New York: Routledge.

Keet, A. 2012. Discourse, betrayal, critique: The renewal of human rights education. In Safe spaces: Human rights education in diverse contexts, ed. C. Roux, 7-28. Rotterdam/Boston/Taipei: Sense Publishers.

Lauritzen, P. 2005. Humanities and atrocities: A response. Journal of the Society of Christian Ethics 25(1): 235-246.

Lechte, J. and Saul Newman. 2013. Agamben and the politics of human rights: Statelessness, images, violence. Edinburgh: Edinburgh University Press Ltd.

Marechera, D. 1986. [1978]. The house of hunger. Harare: Zimbabwe Publishing House.

McClennen, S. A. and J. R. Slaughter. 2009. Introducing human rights and literary forms; or, The vehicles and vocabularies of human rights. Comparative Literature Studies 46(1): 1-19.

Messer, E. 1993. Anthropology and human rights. Annual Review of Anthropology 22: 221-249.

Mpe, P. 2001. Welcome to our Hillbrow. Pietermaritzburg: University of Natal Press.

Osler, A. and Juanjuan Zhu. 2011. Narratives in teaching and research for justice and human rights. Education, Citizenship and Social Justice 6(3): 223-235.

Palumbo-Liu, D. 2012. The deliverance of others: Reading literature in a global age. Durham and London: Duke University Press. 
Peters, J. S. 2012. Literature, the rights of man, and narratives of atrocity: Historical backgrounds to the culture of testimony. In Theoretical perspectives on human rights and literature, ed. E. S. Goldberg and A. S. Moore, 19-40. New York: Routledge.

Roux, C. 2012. A social justice and human rights education project: A search for caring and safe space. In Safe spaces: Human rights education in diverse contexts, ed. C. Roux, 28-50. Rotterdam/Boston/Taipei: Sense Publishers.

Slaughter, J. R. 2006. Enabling fictions and novel subjects: The Bildungsroman and international human rights law. PMLA 121(5): 1405-1423.

Slaughter, J. R. 2012. Foreword. In Theoretical perspectives on human rights and literature, ed. E. S. Goldberg and A. S. Moore, xi-xiv. New York: Routledge.

Solomon, A. 2006. Who gets to be human on the evening news? PMLA 121(5): 1585-1592.

Stanton, D. C. 2006. Foreword: ANDs, INs, and BUTs. PMLA 121(5): 1518-1525.

Szeghi, T. 2012. Review: Elizabeth S. Anker, fictions of dignity: Embodying human rights in world literature. Human Rights Quarterly 36: 244-250.

Twiss, Sumner B. 2005. Humanities and atrocities: Some reflections. Journal of the Society of Christian Ethics 25(1): 219-234.

wa Thiongo, N. 1967. A grain of wheat. Oxford: Heinemann.

Zinn, D. K., R. Adam, J. Kurup and A. du Plessis. 2016. Returning to the source: Reflexivity and transformation in understanding a humanising pedagogy. Educational Research for Social Change 5(1): 70-93. 